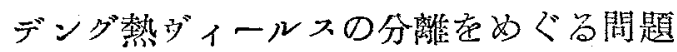

堀田淮*

まえがき

昭和23年 (1948), 東京慈恵醫大におりる日本細菌學 會總會の席上，緮方規雄博士加”“恙虫病々原体の登見 とその命名についでという㴼説层試みられた。それ に對して田宮猛雄，材村廉，北岡正見の諸博士から追

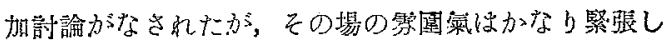
たものを含んていた。筆者昰，自分の父漞に相當する

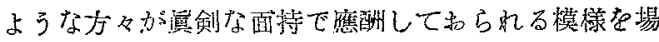

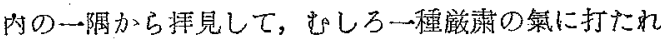
たことな今な和まざまざと想い浮べることがでる。 そして，この問題が蕒理の名によつて充分納得の行く 解決に到達すること考望るかつ惞つたのであるが，と

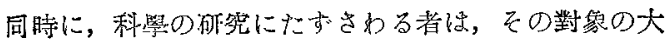
小居䦓わす，すべて物事の附容とか心きさつとか居 分明かにして万人の批判の前に提供する军務があるこ と老萳感した次第である。

ここにとりあげけデング熱の那究は，1943〜1945の 時期に一つの進歩居画したと考光られる。にもかかわ らず，その間に舉げられケ成績局詳細に検討してみる と，必すしし一致した結諭に㒓したとは思われず，か

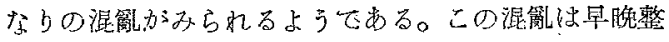
理せられ，問題のあb場所が充分明かにせられねばな らない。その手がかりの一つにもなしたいというのが この諭交の目的である。

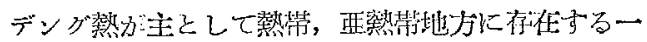

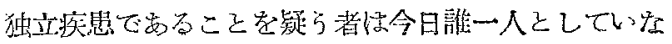
い。本病方初めて嗼載计られたのほ1779年でてるとい われるから (Pepper, 1941), 醫学的認識の刘象と本

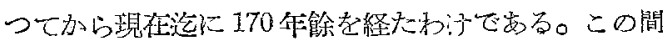
に本病の研究に3の進步名画されたと思う。

1. 本病分晸によつて㚭介されることが知られたこ 飞;

2. 本病バ原䭪惊占ィールスで交ることが知られた こと；劣よび

3. 本少ィールスの分離が逵成讨られたこと； が先机である。

本諭交に和いては，この附主として（3）について述
ベ（1）と（2）とは簡單にふれるに止めけいと思う。 デング熱蚊媒介說

デング熱が蚊によつて媒介されることの可能性を想 定した最初の人は Graham(1903) てあるが，惜しい

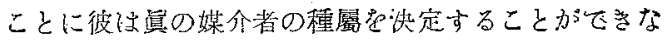
かつた。今日の処，デング熱の媒介畩は Aedes 屬に 限られてふり，なかんすくA. aegypti，A. albopictus および A. scutellarisの3種てあることふ知られてい る。このことにたすさわつた䃑究者は第 1 表の通りで ある。

第 1 表 酷媒介説の磪定 (1906〜1931)

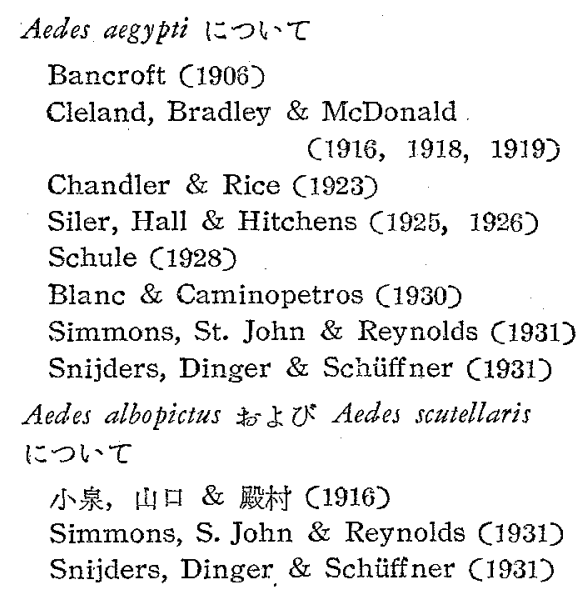

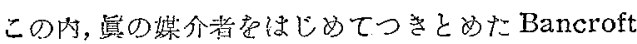
(1906)，小泉，小日\&殿村 (1916) の業績は，今日

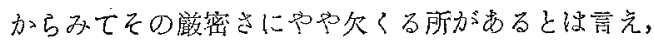
偉とすべ装であり，又 Siler, Hall \& Hitchens (19 25, 1926), Simmons, St. John \& Reynolds (1931) の一点非の打ち所のないデータはこの領域における 不滅の金字塔であると菩つても決して過賞てはあるま 6.

\section{・ デンク㜻原体ヴイールス說}

デング熱の病原体については Babesia 㴍小体，小 球菌, スピロへータ, 原虫, いわゆる globoid body, 双球菌，リアッチアなど (1902〜1929) か発表せられ たが、いすれる確證尼提供しないて終つだ。しかし

\footnotetext{
* 京都大學醫學部微生物學教室 (主任：木村廉教授)
} 
Ashburn \& Craig (1907) 以来，デング蕉の窉原 体市ヴイールスであり，それは一定時期の患者血液邖 に含まれるということは完全に疑のない所である。 第 2 表はこれを磪證した破究者㞎列舉してある。

第 2 表 病原体ヴイールス説の踓定 (1907 1931)

Ashburn \& Craig (1907)
小泉, 山口 \& 殿村 (1916)
Cleland, Bradley \& McDonald
(1918, 1919)
Kligler \& Ashner (1928)
Blanc, Caminopetros \& Manoussakis
(1928a)
Manoussakis (19:8)

\section{デング熱ヴイールスの分離}

このよろにデング熱の卙媒介説や将原體ヴィールス 説忤確立した汁れども，このヴィール不を分離するこ 己は，多くの呼究者の努力にもかか和らず，最近李厄

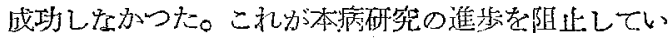
たのである。太平洋粆争の進展 (1941〜1945) と共に

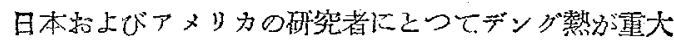
関心專の一つとなつたのでるが，上に述べた歴象的 事情からして, 研究の第 1 の重點がヴィールスの分離
に置かれたの䠝然のことで交つた。

一般にヴイールスの分離に，現在の處，次の手段の

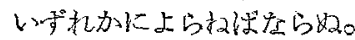

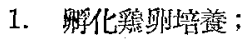

2. 組織境養；および

3. 雪物接種

の3がそれである 従つて，四國の研觉者の多くの 業績は寸べてこのいずれかの内に含东れる方けで女 る。

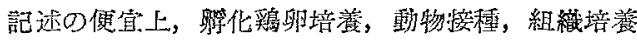
の順に，舉げられた成績寺通觀してみよう。

\section{1. 㬗化彩畉培養}

于で, Shortt, Rao \& Swaminath (1936) はデ

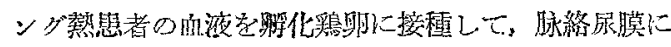
肥厚・結節形成の起るのを認めた。これは，その笑験

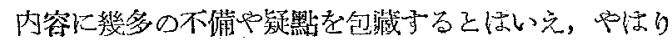

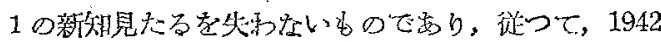
〜1945に和いて多くの研究者が季ず Shortt らの業續

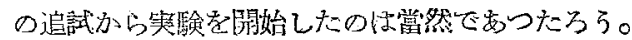

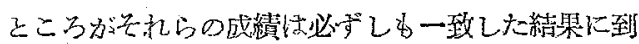
造していないのである。その一尺について詳述するい

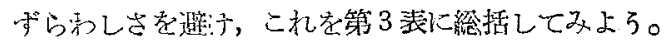

第 3 表

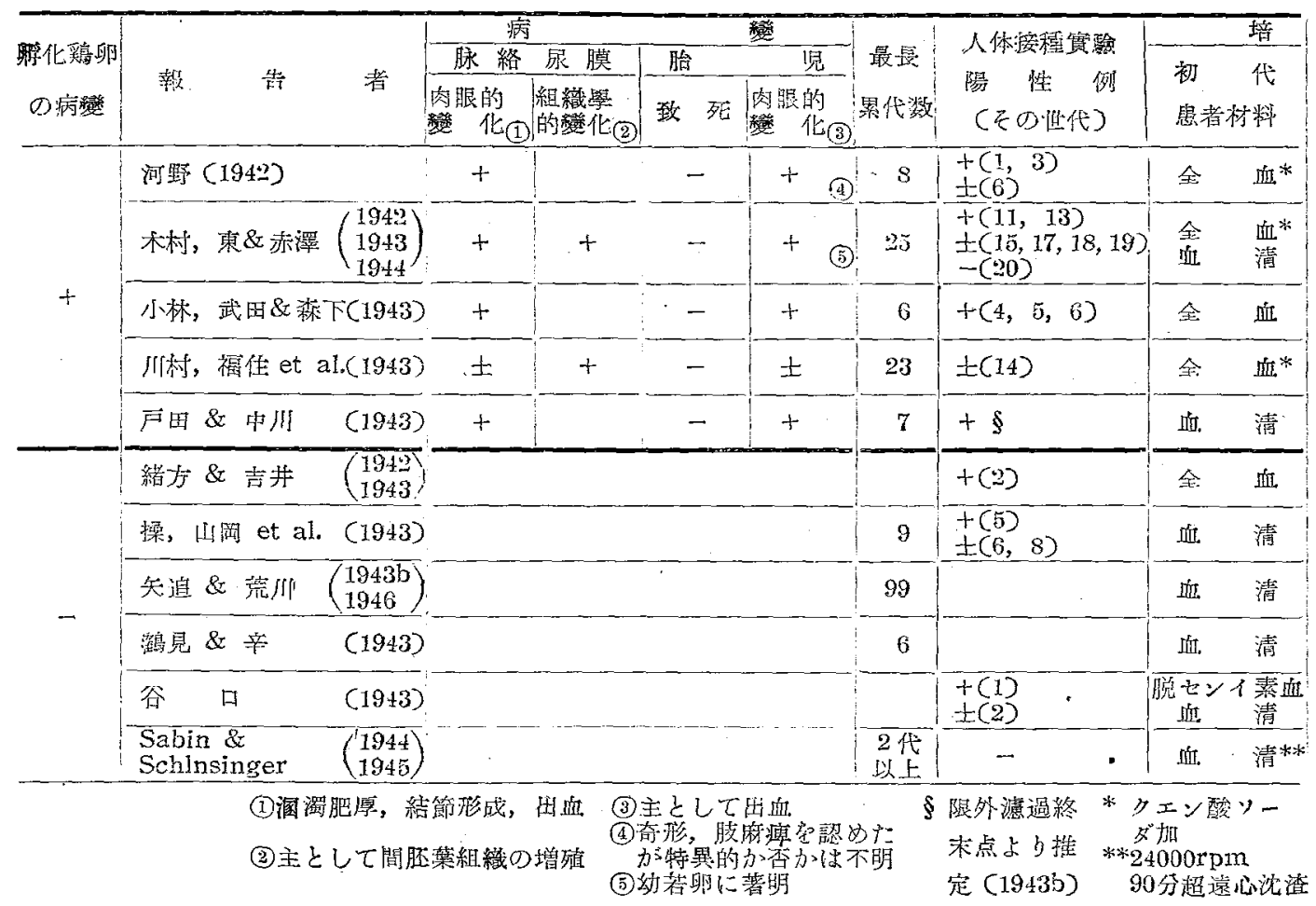


この内 Sabin \& Schesinger はや〉異つた立場学と

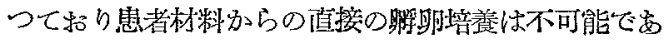

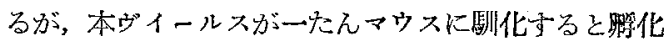
䲲甽内て増殖し得るという (Schlesinger, 1950;1951)

要するに，デング熱ヴイールスの卯化鷄卵による分 離が可能であるかどらか，又この際，鵎卵内に特璂的 な病変か起るかどらかの点について成積が一致しない のである。

\section{2. 動 物 接 種}

Blanc, Caminopetros \& Manoussakis (1928 a; b) はモルモットに就て, Blanc, Caminopetros, Dumas \& Saenz (1929); Simmons, St. John \& Reynolds (1931) はサに拉て，てれてれデング

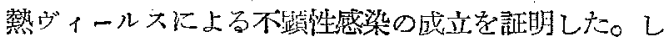
かしこれらの成續はい暗れも本病䂙究の進歩を約束す る程の有㚇性赽もつものではなかつた。こ机以以外の

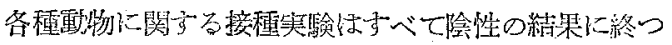
ている(尖触 "綜説" の部参照)。

そころが，1943〜1945に我いて多数の硎究者から動

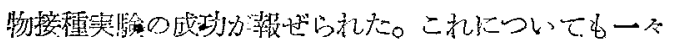
を説睡する代りに，(第4表)に総括して表示すること にしよ 50 第 4 表は一種の壮淮と形容してよいかもし
れない。こそにマス傳達の可能性は研究の進展に光 时を與えるむのですつた。従来のマウス接種成績がす べて除性の成績ですつたのに，今国はそろつて陽性の 成績を得たのでる。

この相異の原因については明かでない。だじしつ だけ言い得ることは，Theiler (1930, Ann. Trop.

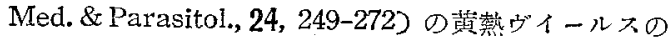

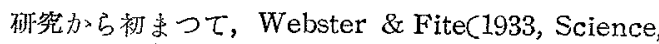

78，463-465̄) のセント・ルイス腦炎ヴィールスの分 離，さらに1935年における日本の破究者たらによる日 本腦炎ヴィールスの分離の成功，などの段管在經て，

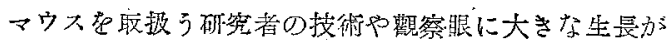
あつたであろうことは磪わである。ここにわれわれは 學的傅統なるすのの一つの意味を見出すことがでさ る。ともあれ，デング熱ヴィールスの動物淁種，とく

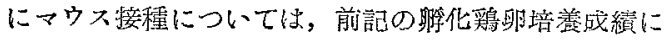
みられたような相異はなかつたわけである。

しからば，閒題はこれを゙落盖したかといらに，決し

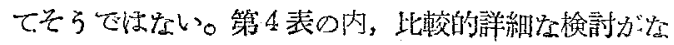
されたヴィールス秼の性状，なかんずく他種䡃物に対 する毒性学摘記してみると，第5表の通りとなる。こ

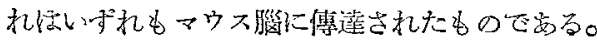

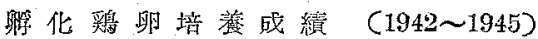

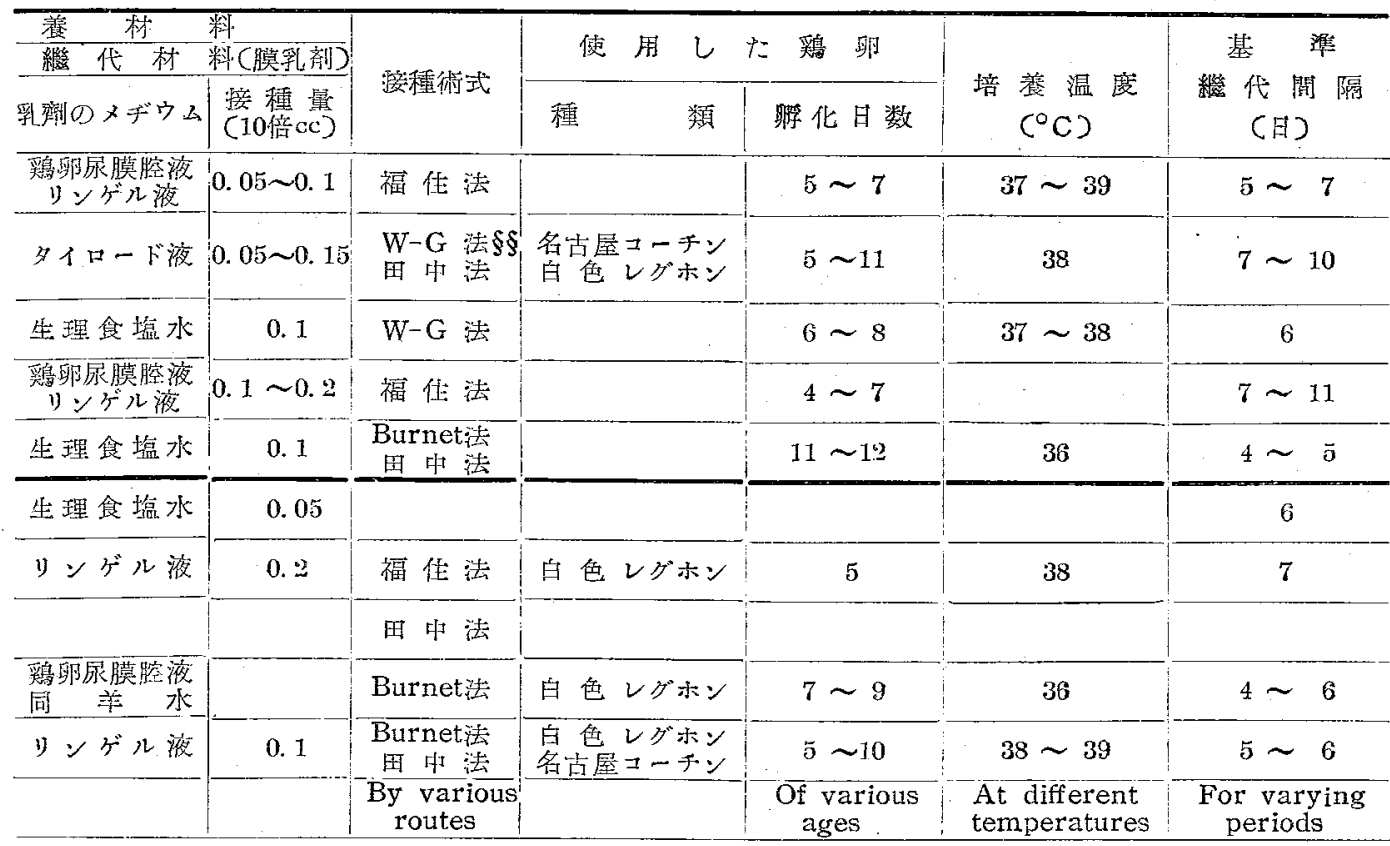

$\S \S$ Woodruff-Goodpasture 


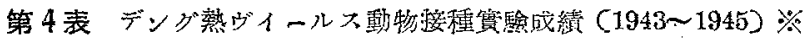

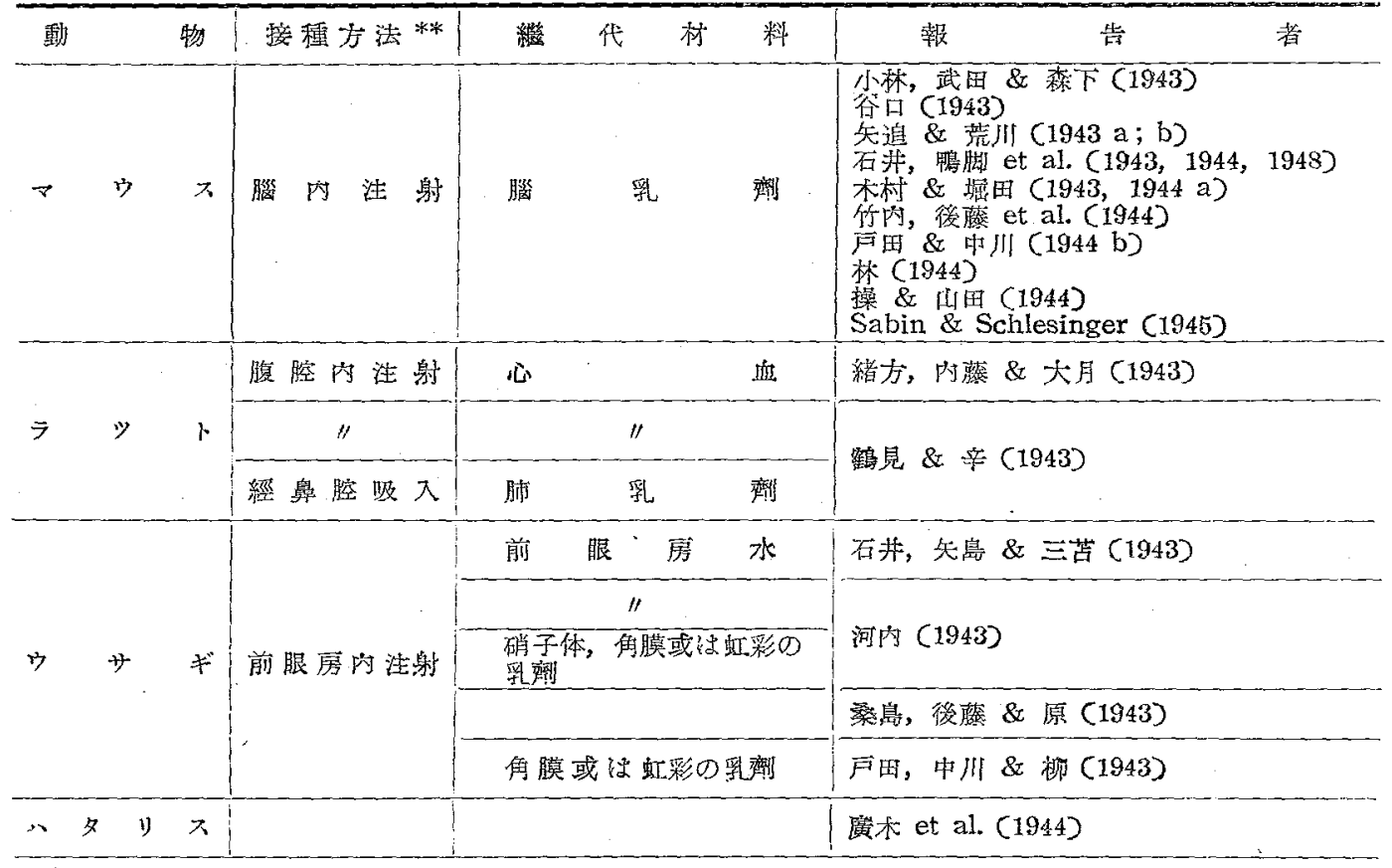

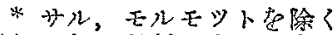

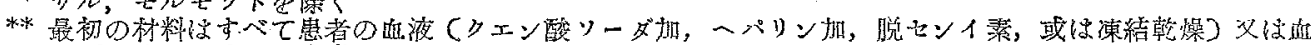

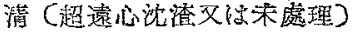

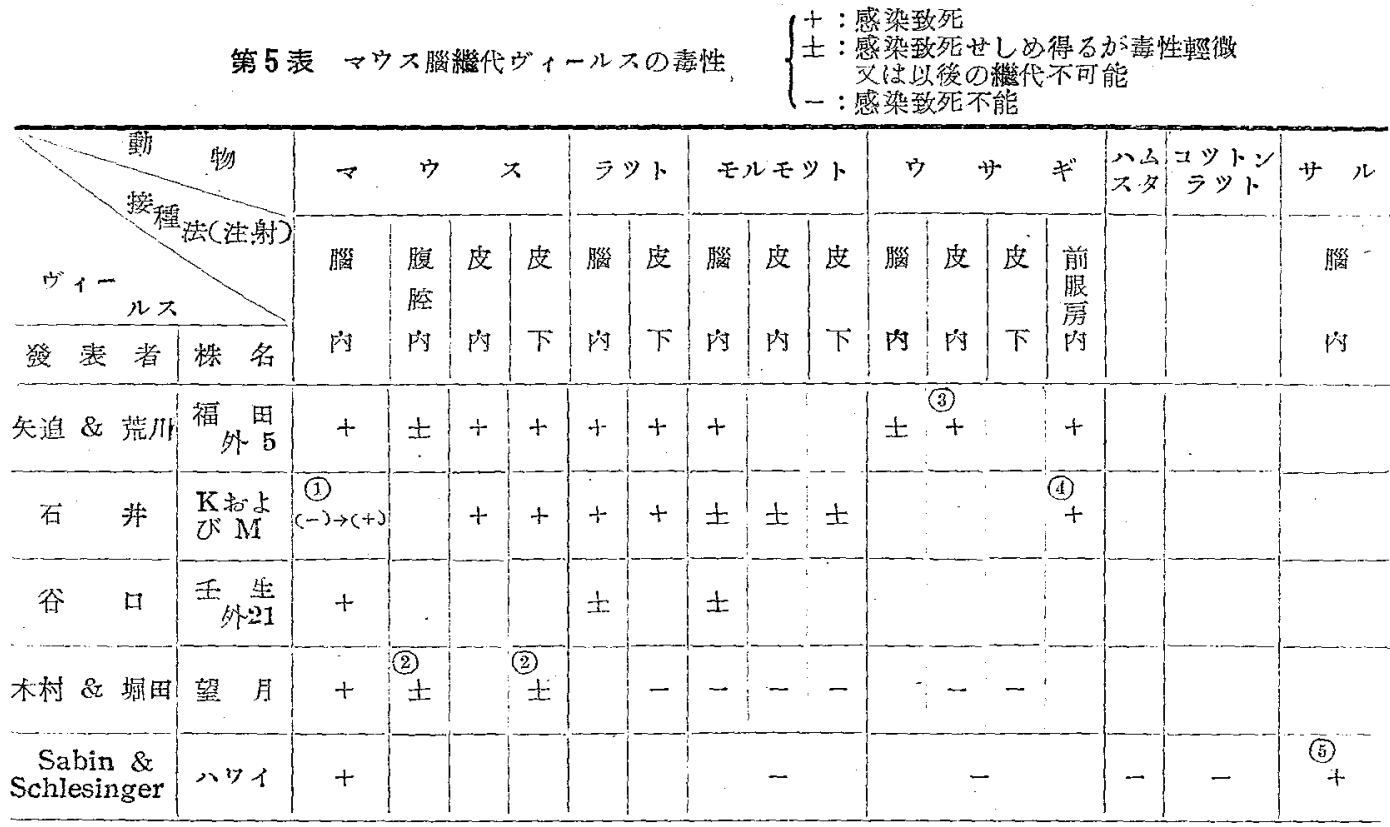

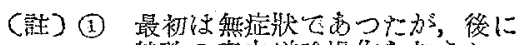

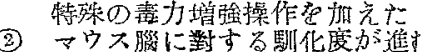 とウス腦に對

(3) 覜椦形成

(4) 硝子体白濁 (b) 發熱，稀に 弛綒性不瘦 
表によると筆者 (木村 \& 堸田) のヴィールスを Sabin \& Schlesinger のヴィールスとはよく似てい る。谷口のヴィールスはこ竌に近いぶ，モルモットに 閶する成績が少し買つている。矢追\&荒川のヴィール ス，石井のヴィールスはこれらと著しい相晎がある。 この㯻笑はどの上ろに理解すべきなのであろらか。

\section{3. 組 織 培 崣}

㭧者材料加らの直接境致と，マウス継代ヴィールス

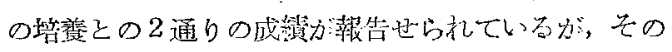
要默は第6 表の通りで安る。

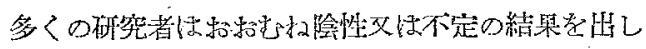

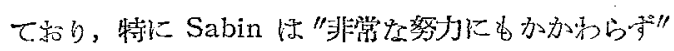
成的し空かつたと述べている。それ㸚し矢息\&荒川

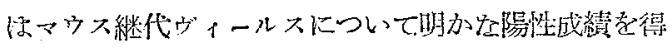

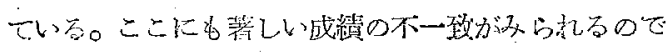
步灰。

\section{ヴィールス分離实驗成績の批判}

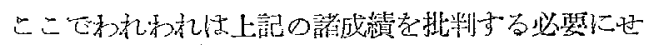
まら礼。

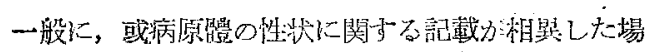

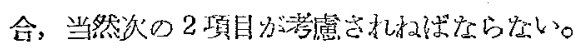

1. 分離された agent が喿して真の病原体で离学 か。い斿れか一方が鿁りではなか力らか。

2. 双方ともが真の病原鹖でるならば，耐者の差

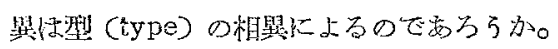

こ礼基いて諭墥老進めてみよう。

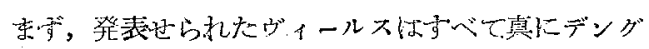

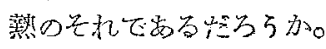

少くよもデング熱に関する隄り(そして原則的には ナ゙゙てのヴィールス病に共通することでするが真の 病原ヴイールス老分敨したと断定するためには，次の 手続泇不可欠の條件で放る(洞田, 1950c)。

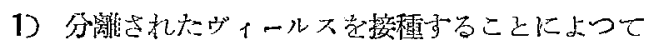
人頭に登型的なデング等症状を起し得ること;

この際，次の 2 默をむ併世溚える必瑟加もる。

a) 自然感染の可能性を絶対除外できるこ

b）䇛状をひ、起したヴィールスは“增殖”したも

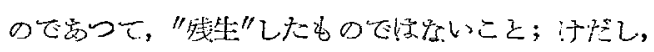

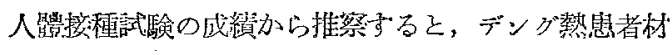
料の最小感葓量はかなり小さいるのでするからく 泉, 山口 \&㡠村, 1916. 緒方\&吉井, 1943), 継代初 期の材料て陽性成續を得たとしても，それは単なる残

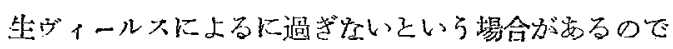

岁夻。

2）このよろに感染した㮯體は，恢復後改めて，自 然のままのデング熱ヴィールス(具䁗的に言光ば，自 然感染㭧者の発病初期の血液了を接程された眭, それ に対寸る感染防丵能を示すこと；和よび

3）人為的並飞自然的感染の恢復血清は分離された ヴィールスに刘する特異的な抗體を有すること； の3が艺的を゙あ。Sabin にこの外にな括

4）分離されたヴイールスをデング鴒媒介装に吸わ した場合, 一定の潜伏期の後に, その蚊か嶨染能力を 帯びるに至ること：

を挙げているが，たしかにもつともなととである。

この3ないし4項目が满足された㭙はじめて, 當該 ヴィールストデング䓡のそれでをると断定することが

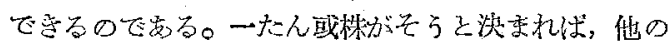

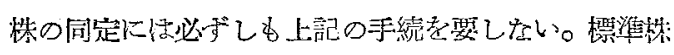

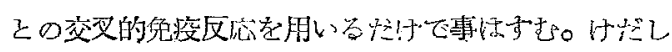

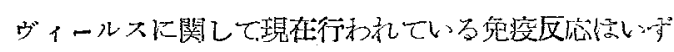
れもか特異度の高いものであるから。

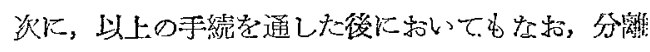
ヴィールスの性状に関する成䄣の相筫することがるり

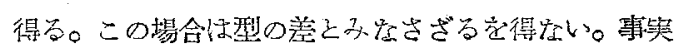
零能逆前所炎ヴィールスや Coxsackie ヴィールスにつ

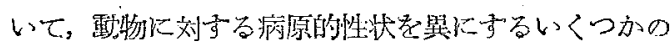
型知られているので志る。

この2點を考慮に入れた上て，前記の諸成績を批判 してみ上ら。

\section{稳化鷄卵培養および組織培養の} 成績について

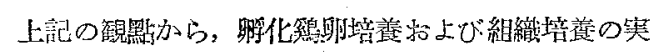

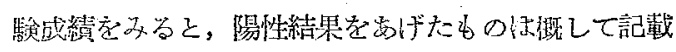
不充分々言わざるを得ない。, その成績が正しいと しても,これらの株のすべてが現在と㤝てしまつて いる以上，これをたしかめるずかがないるといらて，

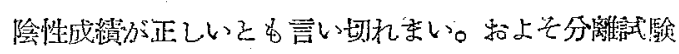
に括いては，10の陰性成績より1の陽性成續が力をも

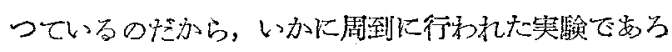
ろとも，㓌性成䊧が絶対であるとは断言できないたる 30

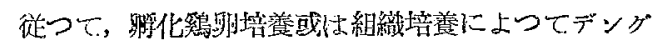
熱ヴィールスを分離できるかどうかという問題は現在

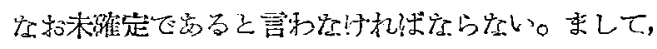
そ机によつてヴィールスの型の區別ができるかどらか といらことは全く不明である。 
第 6 表 デング熱ヴィールス

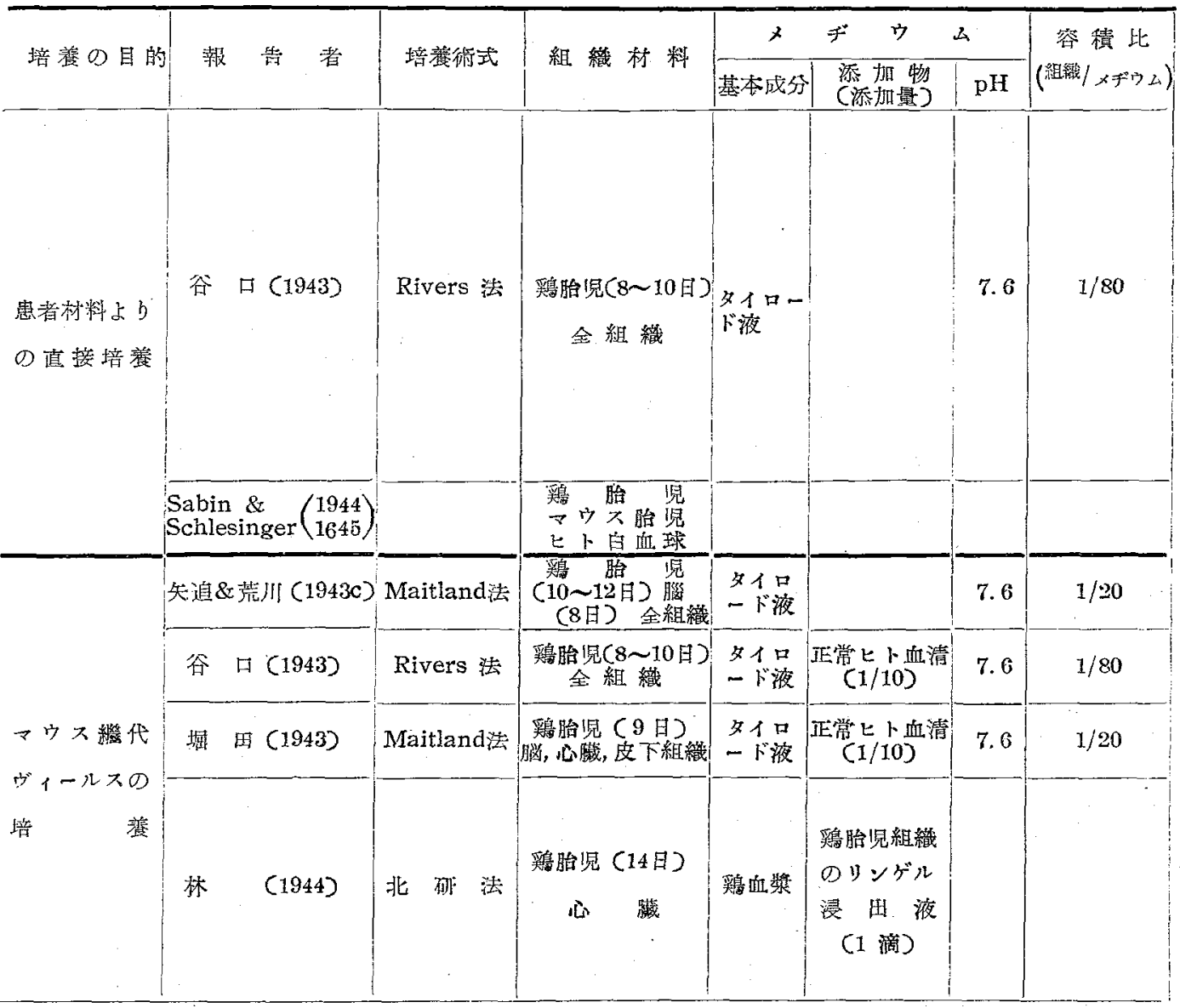

動物接種の成續について

動物接種実験についても遗憾ながら第 4 表の大部分 は記載が不充分である。その内, 完全に若くは完全に近 く記戰のをされているの第 5 表に揭げた 5 ダループ のそれであるからっこれについて批判を加えてみよう。 第5 表けこけについてみると，矢追\&荒川のら゙ィール

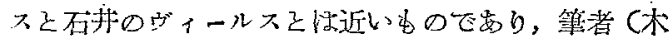
村\&堀田〉のヴィールスと Sabin \&Schlesinger の ヴィールスとはよく似て和り，卻のヴイールスはを の中間にあるよろに思穴る。

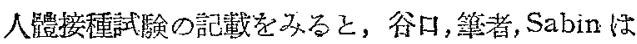
いずれも定型的厓デング熱症状を起さしめているが， 矢追\&荒川赫上び石井のそれはどうも定型的とは言い 難い上ろで嵓る。(失追\&㜔川，1943 a; b; d. 加藤, 矢追\&荒川, 1943. 石井, 䘥脚 et al., 1944. Ishii, 1948)。矢追\&荒川は，これをヴィールスのマウス馿 化度分高いためであるとしているが，それはそれとし

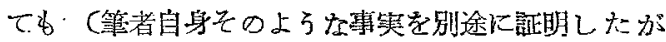

(本村\&堀田，1944b. 堀田，1947；1950b)) それに至

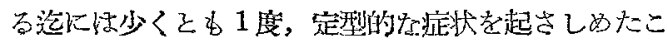
とを立証好叔ばなるすい。

免疾学的な記載，特に血湔中和反応の成漬はいずれ も概ね同様である。

Sabin は, 矢追\&洗川のヴィールスは狂犬病固定毒 石井のそれはりフトバレ一熟ら゙ィールスて茄ると逊べ

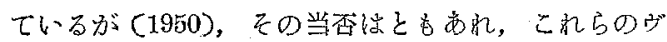
イールスがかなら異つたものてあるうということ紀 載げけからてを容易にう方办い得られる。谷口のヴィ

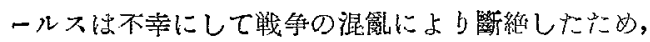
その記䢡老買諭なく證明する手段は永久に失われた。

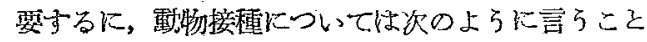
ができだろろ一、ウス腦内接種によつてデング熱 ヴイールズを分離することが可能である。ただし，今 日汽飞報告せられたヴィールスがずてて単一のもので 西ると好思无原い。 
組織培羝成績 (1943～1945)

\begin{tabular}{|c|c|c|c|c|c|c|c|}
\hline \multirow{2}{*}{ 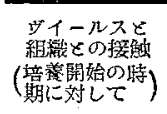 } & \multirow{2}{*}{ 移植の方法 } & \multirow{2}{*}{$\begin{array}{c}\text { 培養温度 } \\
\left({ }^{\circ} \mathrm{C}\right)\end{array}$} & \multirow{2}{*}{ 培盖初代材料 } & \multirow{2}{*}{$\begin{array}{c}\text { 縞代閒隔 } \\
\text { (日) }\end{array}$} & \multirow{2}{*}{$\begin{array}{l}\text { 最長 } \\
\text { 累代数 }\end{array}$} & \multicolumn{2}{|c|}{$\begin{array}{c}\text { 培養結果の判定 } \\
\text { (その世代) }\end{array}$} \\
\hline & & & & & & 人体接種 & マウス腦復元 \\
\hline \multirow{5}{*}{ 同 } & \multirow{5}{*}{$\begin{array}{l}\text { 組緄乳劑究 } \\
\text { 次代に添加 }\end{array}$} & \multirow{5}{*}{37} & \multirow{2}{*}{ 脱センイ素血 } & 5 & 4 & $-(1)$ & \\
\hline & & & & 1 & 7 & $\begin{array}{l}+(1) \\
-(3,7)\end{array}$ & \\
\hline & & & 全 血 & 1 & 7 & $+(1)$ & \\
\hline & & & 血it. 清 & 1 & 7 & $+(3)$ & \\
\hline & & & 血球 & 1 & 7 & $+(3)$ & \\
\hline \multicolumn{2}{|c|}{ By various routes } & $\begin{array}{l}\text { At different } \\
\text { temperatur- } \\
\text { es }\end{array}$ & 血超遠心沈洎) & $\begin{array}{c}\text { For varying } \\
\text { periods }\end{array}$ & & - & \\
\hline 時 & $\begin{array}{l}\text { 組織乳剆峃 } \\
\text { 次代に添加 }\end{array}$ & 37 & 脳乳剆 (11代) & 5 又は 7 & 10 & · & + (各代) \\
\hline 同時 & $" 1$ & 37 & 脳乳劑(1～2代) & 1 & 5 & $-(2)$ & \\
\hline 前 & " & 37 & 脳乳劑心血( こ代) & 5 & 6 & & $\begin{array}{l}+(1,2) \\
\pm(3) \\
-(4,5,6)\end{array}$ \\
\hline 前 & $" \prime$ & \multirow{3}{*}{37} & \multirow{3}{*}{ 脳乳辣(2～3代) } & \multirow{3}{*}{4} & 7 & $\begin{array}{l}-(7) \\
-(7)\end{array}$ & \\
\hline 同時 & 新組織片に併置 & & & & 7 & $\begin{array}{l} \pm(7) \\
-(7)\end{array}$ & \\
\hline 前 & $\prime \prime$ & & & & 11 & $\begin{array}{l} \pm(11) \\
-(11)\end{array}$ & \\
\hline
\end{tabular}

デング熱ヴイールスの整準株について

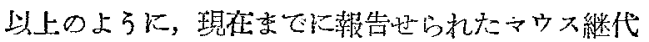

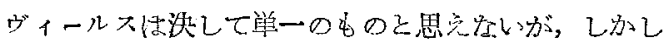
その内のいくつか怯に同一のものと考充られる。す 字方,

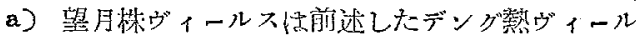
大たる條件の3 項目を満足するもので出るが，その後

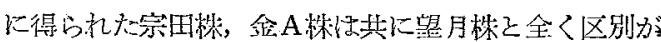
できないこと(堀田，1944）；

b) ハワイ株ヴィールスは前記條件の 4 項目を満足 しているが，その後に分離せられたニューギ二アA，

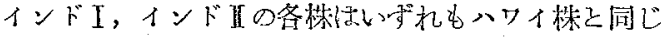
型に属すること（Sabin，1948；1950）拈よび

c) 望月株とハワィ株とは生物学的・兔疫学的に同 じであること(Sabin，1948；1950) が知られているの である。

従つて, 少くともここに挙げた 7 株は同一性状のむ
のと考えね2ばならない。

しからばデング䩓ヴィール大はこれだけに限るの

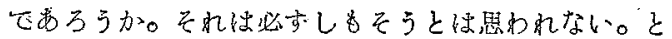
いうのはデング髙ヴィールス教疫反准の上から少 くとも2 型に區別すること为可能でる。 Sabin C19

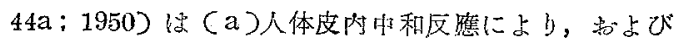
(b) 上ト拈よびサルにまりる對ハワイ株ヴィールス 中和执体虎測定することによつて，有毒患者利料か施 疫學上さ群に分たれること灵示したのてある。従つて 将来，上記の7株又はこれと同一のもの例えばデン

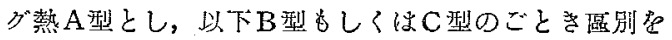
する必要が起るかもしれない。他種のヴィールスの場 合とくらべてみても，その可能性はたしかに認められ るのである。しかし現在の虎，そうだと斷定するため

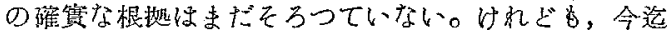
に述べてきた諸家の成續の不一致宫，もしかしたらそ の原因がこのような型の區別にあるのかもしれないの 


\section{(44) 194}

である。そうであるか，或はるうでないかの決定は， 勿諭な和將来の检討にまけ炇ばならないげるう。

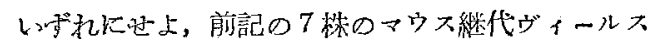
は疑なくデング熱ら゙ィールスであり，かつ恐らくは同 一の型に属するむのであろろと結諭することがてき

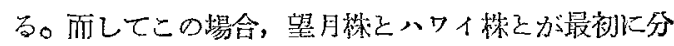
離せられ，かつ，詳細た記載がなされたという急味で 梅準株に定められるべきでるる

これらの點を䒾示してみると第7表のごとくにな る。

第7表 デング熟ヴィールス標準秼

(名稱，分離者，分離時期放上び分誰場所)

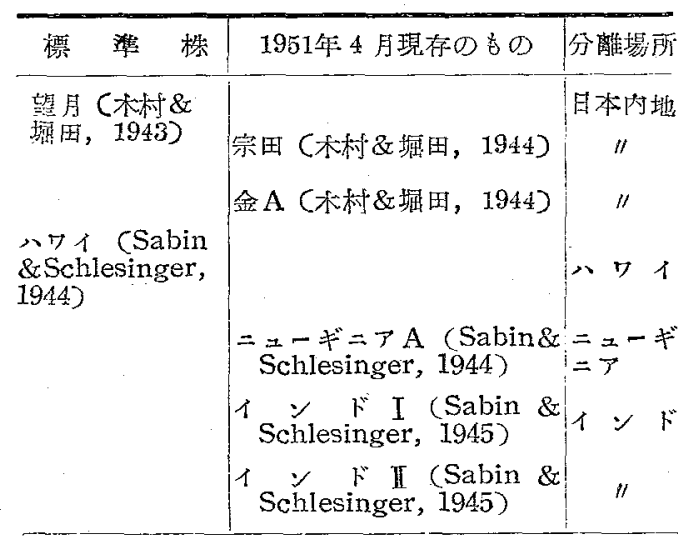

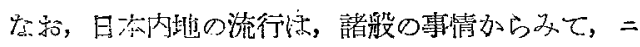

ニーギニア，フィリッピン方面より由来したもので市

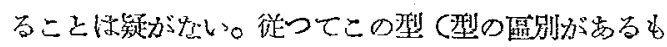
のと假䇥して)のデング謺ら゙ィールスは太平洋加ら印 磨洋に亘爷公い垉淢に撒有されていると考光られる。

$$
\text { 總括 }
$$

以上学総括すると，

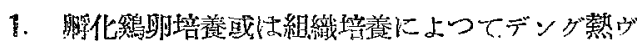

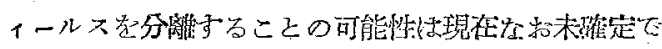
多る;

2. マウス腦内接種によつてデング算ヴィールスの 分離が可能である，と言らことができる。

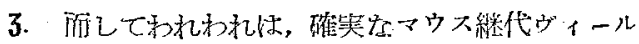

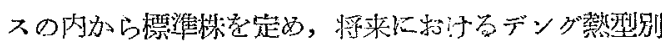
決㘹のよりどころとすることが妥当で要りかつ必要て

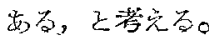

\section{其他の新知見一二}

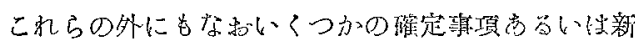

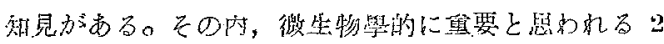
点について簢㖛に述べて和こう。

第1は，デング蓺ヴィール大の大きさ方渭青された

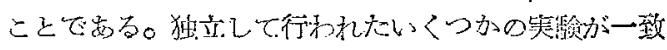

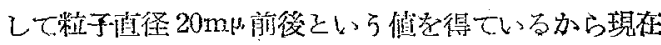

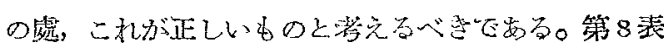
にこれ学一括表示した。

第 8 表 デング熱ヴィールス粒子の大学さ

\begin{tabular}{|c|c|c|c|c|}
\hline 材 & 告 & 沋定の方法 & $\begin{array}{c}\text { 粒子D直徑 } \\
(m \mu)\end{array}$ & 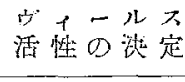 \\
\hline \multirow{3}{*}{ 蝟者 侻 清 } & F时 \& 计 川 (1944a) & 限 外滤 滑 & $15 \sim 23$ & 人体㼋種 \\
\hline & Sabin $(1944 b)$ & $\quad \|$ & $<17 \sim 25$ & $" \prime$ \\
\hline & Sabin (1948) & $\prime \prime$ & $15 \sim 22$ & $" \prime$ \\
\hline 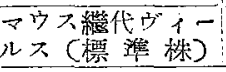 & 牕 田 (1950) & 䉓子熙微醷撮影 & 20 前後 & マウス脳復元 \\
\hline
\end{tabular}

第2は，マウ大腦内通過によりデング熱ヴィールス

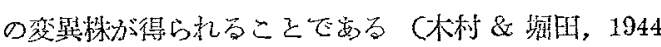
b.溜田, $1947 ; 1950$ b. Sabin \& Schlesinger, 1945. Sabin, 1943; ; 1950)。こ虬によて有效立子防接種

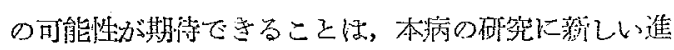
展老約束与るものだる万ら。

\section{あとがき}

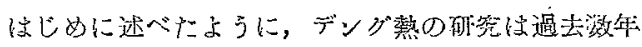

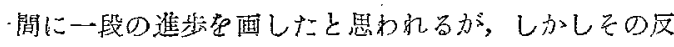

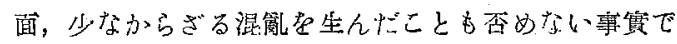

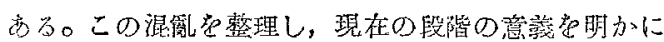

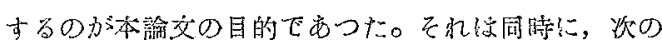

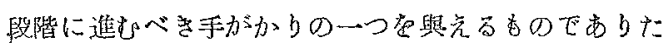
s。

それにつけても，本病㼋究において月本の河究者の 果した役割が少くなかつたこと究敘記したいと思う。 新しい進屡の段階昰に日本人が主役を演したという題

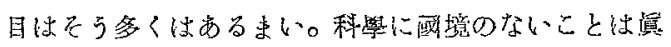
理てあろうけれども，一国の祭然の成果肪とつてもつ

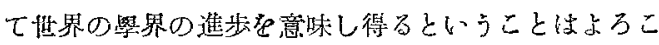


ぶベきことがらにちがいない。

最後に，恩侕林村廉教授の慈始か力らざる御厚情を

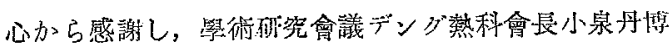

\section{原著 (著者名 $\mathrm{ABC}$ 順)}

Ashburn, P. M. \& Craig, C. F. : 1907, Experimental investigations regarding the etiology of dengue fever. J. Inf. Dis., 4, 440-475.

Bancroft, T. L. : 1906, On the etiology of dengue fever. Austral. Med. Gaz., 25, 17-18.

Blanc, G., Caminopetros, J. \& Manoussakis, E.: 1928a, Quelques recherches experimentales sur la dengue. Bull. Soc. Path. Exot., 21, 535-537.

Blanc, G., Caminopetros, J. \& Manoussakis, E. : 1923b，綜镪 (Doerr) より引用.

Blanc, G., Caminopetros, J., Dumas, J. \& Saenz, A. : 1929, Recherches experimentales sur la sensibilite des singes inferieurs au virus de la dengue. Compt. Rend. Acad. Sci., 188, 468-470.

Blanc, G. \& Caminopetros, J.: 1930, Recherches experimentales sur la dengue. Annal. l' Inst. Pasteur, 44, 367-436.

Chandler, A. C. \& Rice, L. : 1923, Observations on the etiology of dengue fever. Am. J. Trop. Med., 3, 233-262.

Cleland, J. B., Bradley, B. \& Mc Donald, W. : 1916, On the transmission of Australian dengue by the mosquito Stegomyia fasciata. Med. J. Austral., 2, 179-184; 200-205.

Cleland, J. B., Bradley, B. \& Mc Donald, W. : 1918, Dengue fever in Australia. J. Hyg., 16, 317- -418.

Cleland, J. B., Bradley, B. \& Mc Donald, W. : 1919 , Further experiments in the etiology of dengue fever. J. Hys., 18, 217-254.

Graham, H. : 1903, The dengue ; a study of its pathology and mode of propagation. J. Trop. Med., 6, 209-214.

林 博: 1944,デング熱病原に關すを知見補遗；特に 羅患發症マウス諸藏器にお沙る病理組織學的所見に

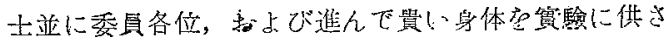

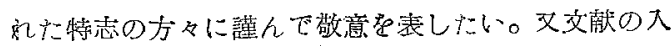
手について好意存いだげいたシンシナナ大學 Albert

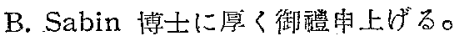

交献

$$
\begin{array}{ll}
1942: \text { 昭17 } & 1945: \text { 昭20 } \\
1943: \text { 昭18 } & 1946: \text { 昭21 } \\
1944: \text { 昭19 } & 1947: \text { 昭22 }
\end{array}
$$

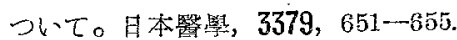

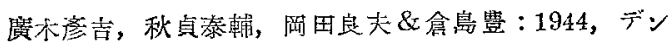
グ熱に關する砄筲 (その1);デング热病毒のハタリ 大(Citellus mongolicus ramosus Thomas) 淁種 試驗. 第18回日本絀菌學會演説要旨 pp. 62-63. 堀田進: 1943，デング樊病毒組蟣培養战績. 未發表.

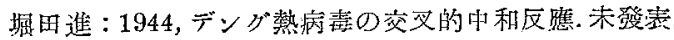

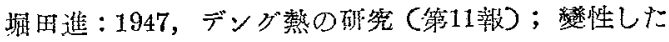
病毒について。目本登學，3413，89-90.

堀田進: 1950a，同上(第21報)；ヴィールスの化学的

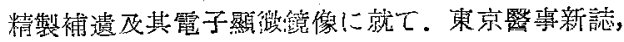
67 (9), $7-8$.

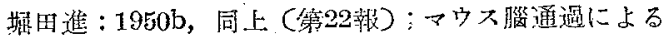

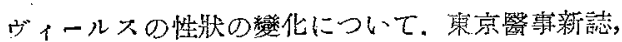
$67(11), 19-22$.

堀田進 : 1950c,デング熱砳筧㞎通してみたヴィールス 學的閭題の二三について。ヴィールス談話會記録。 石半信太郎，矢島嘉清\&三苫嚆子 : 1943，デング熱に

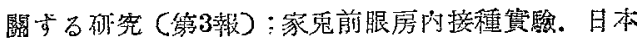
醫學, 3317, $156-158$.

石井信太郎, 鴨脚光堌\&福田雅夫：1943，同上 (第出報) ; マウス腦内接程偊驗，日本醫學，3321，344--345. 石井信太郎，鴨脚光堌，矢島嘉清，三占靖子，大串卓 朗\&术村京子：1944，同上(第6竬)；増強病毒!關

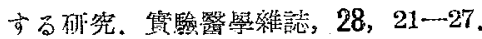

石井信太郎, 福时猚夫\&杢村原子: 1944, 同上C躬10 報〉; ラッテ感染筫䅷. 月本醫學，3379，649-651. Ishii, N.: 1948, Studies on dengue fever. I.Studies on dengue virus and immunity (1). Jap. Med. J., 1, 160--175.

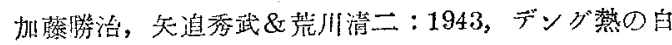
血球像に就七。 日本血液會誌，7，(7)，24一28.

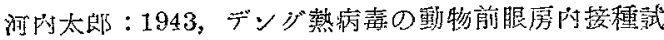
驗. 日本醫學, 3343, 1340-1344.

川村薮地，福任定吉，伊東忠一，伊東平入，高术静治

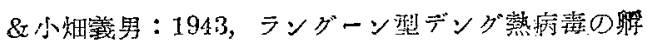


化稂卵附の培養成績について，日本醫學，3321，33 5-342. (Kulturelle Ergebnisse im bebrüteten Hühnerei von Dengueerreger, Rangoon Typ. Kitasato Archiv. Exp. Med., XX (1), 1-26).

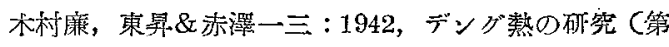

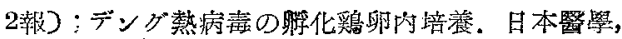
3312, 2595-2599.

木村廉, 東昇, 赤濹一三\&松本節郎 : 1943, 同上(第

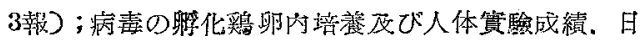
本醫學，3335，993-995.

Kimura, R., Higashi, N. \& Akazawa, H. : 1944, Ueber die Züchtung des Denguevirus auf der Chorioallantoismembran von Hühnereiern. Jap. J. Med. Sci., Part VI (Bacteriol. \& Parasitol.) II (4), 241-246.

森村廉\&墟田進：1943，デング熱の孤究 (第与報)；マ ウス接種赛驗成續。目本醫學，3344，1378一1379.

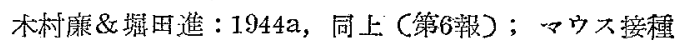

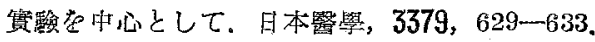
木村廉\&垭田進： $1944 \mathrm{~b}$ ，同上；生窉毒による人体予

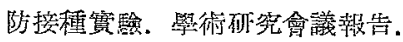

Kligler, I. J. \& Ashner, M. : 1928, Studies on the etiology of phlebotomus and dengue fever. $\mathbb{I}$. Is a leptospira the causative virus. Annal. Trop. Med. \& Parasitol., 22. 151-159.

小林英一，武田徳睢\&菻下櫓：1943，デング營病原体

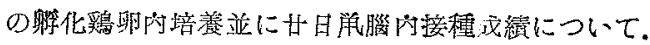
日本醫學，3319，241一244。

小泉丹, 山口䜕爾\&殿村京造：1916(大5)；デング鵁 について，日新嶇學，6，955-1004。

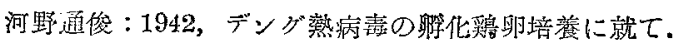
獨立自動車第101大隊記録 (軍䜿團誌，358，259$272,1943)$

桑島像夫, 後藤壽作\&原東太郎 : 1943, Dengue 㸓に

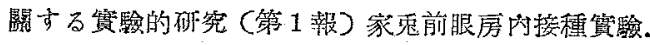
日本醫學，3325，531-534.

Manoussakis, E. : 1928, Recherches etioiogiques sur la dengue. Bull. Soc. Path. Exot., 21, 200-205. 操暏道, 山仙慧二, 山田泰, 光野儀, 小岩井竟策, 一 瀨仁郎，岩倉源駒\&久志本元也：1943，デング等に

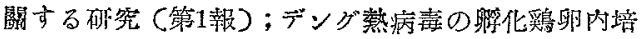
堎について，日本醫學，3321，342-344。

操坦道\&山田弘：1944, 同上(第6 報); デング薙病毒 のマウス接種筫驗。日本醫學，3399，1069-1072.
䋨方规雄\&吉井宗武 : 1942, デング整病害导以ての發 熱短法. 日本醫學，3311，2544-2546.

緒方規雄＆吉井宗武：1943，デング熱病毒の分離，保存 及性状に關する破嵒。日本䣽學，3338，1124一-1128， 緒方規雄，内漛主一\&大号明 : 1943，デング熱病毒ラ ツテ接種實驗. 學少研究會議報告.

Pepper, O. H.P. : 1941, A note on David Bylon and dengue. Ann. Med. History, 3, 363-363 (綜説(Sabin)子少引用)

Sabin, A. B. : 1944a, 綜説(Sabin)上b引用.

Sabin, A. B. : 1944b，紜説(Sabin)上 b用.

Sabin, A. B. : 1948, Recent advances in phlebotomus and dengue fevers. Proc. 4th International Congr. Trop. Med. \& Malaria, 520-525.

Sabin, A. B. : 1950, The dengue group of viruses and its family relationships. Bacteriol. Review, $14,225-232$.

Sabin, A. B. \& Schlesinger, R. W.: 1944, 綜説 (Sabin)より引用.

Sabin, A. B. \& Schlesinger, R. W. : 1945, Production of immunity to dengue with virus modified by propagation in mice. Science, 101, 640-642,

Schlesinger, R. W. : 1950, Propagation in chick embryos of the Hawaiian strain of dengue virus. I. Sustained serial passage in eggs after one hundred and one intracerebral passages in mice. Am. J. Hyg., 51, 248-254.

Schlesinger, R. W. : 1951, Propagation in chick embryos of dengue virus, Hawaiian Strain. $\mathbb{I}$. Findings in infected eggs. Proc. Soc. Exp. Biol. \& Med., 76, 817-823.

Schule, P.A.:1923, Dengue fever ; transmission by A.des aegypti. Am. J. Trop. Med., 8, 203-213. Shortt, H. E., Rao, R. S. \& Swaminath, C. S. : 1936, Cultivation of the viruses of sandfly fever and dengue fever on the chorio-allantoic membrane of the chick-embryo. Ind. J. Med. Res., 23, 865-370.

Siler, J. F., Hall, M. W. \& Hitchens, A. P. : 1925, Results obtained in the transmission of dengue fever. J. Am. Med. Assn., 84, 1163-1172.

Siler, J. F., Hall, M. W. \& Hitchens, A.P. : 1926, Dengue; its history, epidemiology, mechanism 
of transmission, etiology, clinical manifestations, immunity and prevention. Philippine $J$. Sci., 29, 1-304.

Simmons, J. S., St. John, J. H. \& Reynolds, F. H. K. : 1931, Experimental studies of dengue. Philippine J. Sci., 44, 1-251.

Snijders, E. P., Dinger, E. J. \& Schüffner, W. A. P. : 1931, On the transmission of dengue in Sumatra. Am. J. Trop. Med., 11, 171-197.

竹付松㳄郎, 後藤正勝, 齊藤福洽, 竹川勳, 白山義雄 \&宓原音吾 : 1944, デング熟病毒の㗞觉。第18回日 本細菌學會演説要旨 p. 65 .

谷口腆二: 1943 , デング熱病原及免疼に彨する砳究. 第

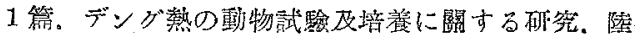

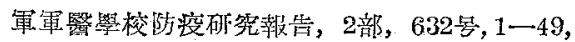

户田忠雄\&㠲川洋：1943a，デング繁病原体に關する

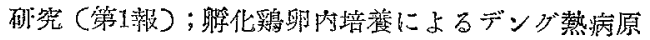

体の大き測定，日本醫學，3331，831一834。

户田忠雄\&中川洋 : $1943 \mathrm{~b}$ 。同上 (第2 2 報)；人体接種

によるデング熱病原体の大きさ測定。日本醫學，33

$32,877-878$.

戸田忠雄\&中川洋：1944a，同上 (第4報)；デング熱

病原体の大ささ砳究補遗. 日本醫學，3368，302 -303 .

户田忠雄\&中川洋：1944b。同上 (第6報) ; 動物試驗

(マウス腦内接種) 成績. 日本醫學，3379，647一 649 .

戸田忠雄, 中川洋\&柳駿 : 1943, 同上 (第3 報); 家鬼 前眼房付接種成續，日本醫㦛，3333，919-921.

鹤見三三\&辛鈞：1943，デング熱病毒に關する破究

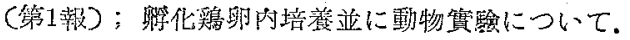
日本醫學，3341，1253-1255.

矢追秀武\&荒川清二：1943a，デング熱の病毒に阆す

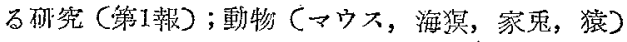
接種成續について，日本醫學，3319，244一247。 矢追秀武\&荒川清二・・1943b, 同上(籰1報); 諸野物

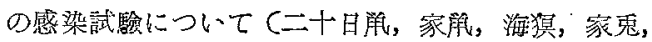
猿) (附) 人体試駼. 實驗醫學雜誌，27, 310-313 矢追唀武\&荒川清二：1943c，同上 (第2報)；デング 熱病毒の Maitland-Maitland による培養につい

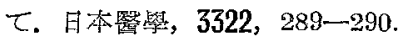

矢息秀武 \&荒川清二 $: 1943$ d, 同上 (第6 報)； マウス

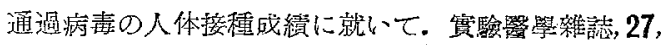
497-498.

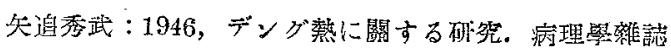
$4,17-22$.

\section{線 說 (發表年代㑯)}

森下葆 : 1925 (大14)，デング熟と枚との關係に關す る知見の変遷及現況。辜灣醫學會誌，247，945一959，

Cleland J. B. : 1930, Dengue fever. A System of Bacteriology, HMS Stationary Office, London, 7, 376-385.

Doerr, R. : 1930, Pappatacifieber und Dengue, Handbuch d. pathogen. Mikroorgan. (Kolle, W., Kraus, R. \& Uhlenhuth, P.), Gustav Fischer,

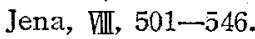

森下薰：1931(昭6)，デング熱（特に近代に拈けると

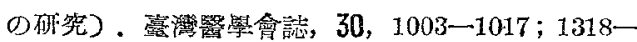
1333.

Manson-Bahr, P. H. : 193ð̄, Dengue. Tropical Diseases, Cassell, London, 360-366.

Schilling, C. : 1939, Denguefieber. Handbuch d. Viruskrankheiten (Gildemeister, E., Haagen, E. \& Waldmann, O.), Gustav Fischer, Jena, 488 $-498$.

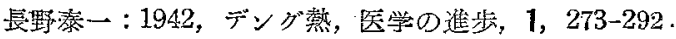
森下薰 : 1943, デング熱の病原体と傅搯者.

憼帶䝷學, 1, 167-188

Strong, R. P.: 1944, Dengue and dengue-like fevers. Stitt's Diagnosis, Prevention and Treatment of Tropical Diseases, Blakiston, Philadelphia, Ed., 7 II, 905-922.

Mackie, T. T., Hunter, G. W. \& Worth, C. B. : 1945, Dengue and dengue-like fevers. A Mannual of Tropical Medicine, Saunders, Philadelphia, 19-22.

Napier, L, E. : 1946, Dengue sand-fly group. The Principles and Practice of Tropical Medicine, Macmillan, New York, 312-320.

喔田進 : 1947，デング熱破究に和ける最近の知見. 日 新医学, 34, 252-259.

Dubois, A. \& van den Berghe, L. : 1948, Dengue. Diseases of the Warm Climates, Grune \& Stratton, New York, 193-197.

Sabin, A. B. : 1948, Dengue. Viral and Rickettsial Infections of Man (Rivers, T. M.), Lippincott, Philadelphia, $445-453$. 